DOI: 10.20472/IAC.2019.046.025

\author{
NUGZAR TODUA \\ Ivane Javakhishvili Tbilisi State University, Georgia
}

\title{
ATTITUDE OF GEORGIAN CONSUMERS TO HEALTHY NUTRITION
}

\begin{abstract}
:
Work shows that in the modern conditions particular attention is paid to in-depth studying of the population's practices of healthy nutrition, as dietary norms, traditions and customs comprise integral part of everyday life. Regarding the mentioned, the work analyses the situation with respect of population's healthy nutrition in Georgia and in the world and identifies the key problems related to it. Attention is focused on the fact that for modern Georgia healthy nutrition is a significant problem and this is reflected in buying behavior of Georgian consumers. Article underlines the role of social marketing in ensuring consumers' healthy nutrition. It emphasizes significance of food labeling, as a marketing instrument for consumers awareness in healthy nutrition. For the purpose of clarification of Georgian consumers' attitude to healthy nutrition the marketing research was conducted. The research showed the levels of the respondents' awareness in healthy nutrition, attitude of the consumers and their trust to the information on the food packages. With respect of attitude to healthy nutrition, the work identifies the consumer types. Applying dispersion analysis we have showed impact of the consumers' awareness, as well as trust to the information on the food packages on buying behavior in relation to healthy nutrition. On the basis of the conducted research the conclusions were made that allow formulation of global vision of Georgian consumers' attitude to healthy nutrition.
\end{abstract}

\section{Keywords:}

healthy nutrition, Georgian consumers, marketing research, awareness, food labeling

JEL Classification: M31 


\section{Introduction}

Providing healthy nutrition to the population is the most significant objective in any country. According to assessment of the experts of World Health Organization (WHO), one of the most significant determinants of people's health and well-being is healthy nutrition (World Health Organization, 2018). According to the data of Food and Agriculture Organization of the United Nations (FAO), every third individual in the world suffers from malnutrition, every ninth is half starved. It should be also stated that malnutrition is responsible for $45 \%$ children mortality and over two billion people suffer from lack of micronutrient elements (Food and Agriculture Organization of the United Nations, 2017). According to WHO studies, factors conditioning malnutrition are quite diverse. Among them the most significant are the following: low incomes of the population; lack of permanent access to proper quantities of the food products of adequate quality corresponding to the religious, cultural and traditional norms, as well as individual nutrition habits. WHO experts regard that nutrition disorders (malnutrition, lack of micronutrient elements, excess body weight and obesity, as well as non-infectious diseases caused by unhealthy food) causes serious economic and social losses (World Health Organization, 2014). Economic, social and medical outcomes of malnutrition impact development of not only certain individuals and their families but entire society as well (Food and Agriculture Organization of the United Nations, 2016).

In 2012, European Regional Committee of WHO has adopted document "Health - 2020: a European policy framework and strategy for the 21st century". It underlines the idea that health and welfare is the necessary condition of economic and social development (World Health Organization, 2013). In 2014, at the II International Conference organized jointly by $\mathrm{FAO}$ and $\mathrm{WHO}$, the participant states and world community undertook the obligation to eliminate the above mentioned problem. General conception of global actions related to malnutrition formulated in Rome Declaration provides framework action program. In includes 60 recommended actions that the governments can include for development of their national plans in the spheres of food, healthcare, agriculture, education and investments (Food and Agriculture Organization of the United Nations, World Health Organization, 2014).

In 215, United Nations adopted the resolution on sustainable development for the period before 2030, where particular attention is paid to dealing with the malnutrition problems. It is known as goal 2 of sustainable development (United Nations, 2015). On the basis of this document, in April 2016, UN has published its resolution containing ten-year action plan related to nutrition, in 2016-2025 (Food and Agriculture Organization of the United Nations, World Health Organization, 2015). Regarding the above, in May 2016, FAO and $\mathrm{WHO}$, in collaboration with World Food Program (WFP), International Fund for Agricultural Development (IFAD), United Nations International Children's Emergency Fund (UNICEF) and other international organizations, based on Rome Declaration, have 
developed the framework action program related to the nutrition issues (World Health Organization, 2016). It describes key priorities and guidelines, for 2016-2025 period, related to the nutrition problems, also forms and conditions of participation of the governments and other stakeholders.

According to FAO report for year 2017, irrespective of significant measures for elimination of malnutrition, in the European and Central Asian countries about 14.3 million people are unable to secure sufficient food for themselves. Analysis of food security and nutrition situation in the countries of Europe and Central Asia is provided based on the relevant indicators, allowing evaluation of the countries' progress to achievement of sustainable development by 2030 (elimination of the problem of hunger, ensuring food security, improvement of nutrition and sustainable development of agriculture). There are also evaluated the nutrition indicators, such as suspension of growth in height, weakness of human organism, anemia, obesity, changes in dietary regime and their impact on different groups of population. In addition, according to WHO data, the main cause of the above problems is inadequate alimentation, at least one of three types of which (undernutrition, overnutrition and deficiency of micronutrients) is registered in each of the countries of Europe and Central Asia (Food and Agriculture Organization of the United Nations, 2017).

Healthy nutrition is a significant problem in modern Georgia. According to the study conducted by British organization Oxfam, food patterns of Georgian population is still unsatisfactory. It is characterized with high energy content, resulting in excessive weight and obesity. Nutrition of the most part of the population is inadequate and irregular and this is the cause of numerous diseases. Share of poor population suffering from undernutrition is quite high. Due to the existing economic situation, most Georgian consumers, for the sake of saving of money, buys cheap products. Today most part of the expenses falls on food and the ration is unbalanced. Such trends affect negatively the population's health (Oxfam Georgia, 2017).

Study of the consumers' attitude to healthy nutrition is the most issue of social marketing and it is a determinant of the society's welfare (Donovan, 2011). The literature dealing with social marketing pays great attention to studying the influence of modern life style on nutrition practices and what are the changes related to everyday nutrition. Some authors regard that in the recent years the significance of traditional family table gradually fades and nutrition becomes more and more individualized (Caplan, 1997). Daily food is regarded as a social phenomenon including three key dimensions: dietary regime, food composition and its social organization (Fischler, 1988). Such approach allows considering dietary practice in the sociocultural context and identifying the relationships between food, its social nature and daily behavior (Charles and Kerr, 1988).

There are numerous factors affecting consumers' attitude to healthy nutrition. First of all, this is awareness in nutrition information and its use in choosing the food products, 
mostly depending on the subjective characteristics and personal qualities of the consumers, such as age, interest to the healthy customs and social status (Grunert et al., 2010). Therefore, the marketing professionals took into consideration the consumers' requirements to their health and welfare to maximal possible extent, when choosing the food products. In the recent period, demand for the food products that contribute to health maintenance has increased significantly. And this, in turn, stimulates the food producing enterprises to develop the innovative products with advanced consumption properties (Robinson, 2014). Though, it should be mentioned that many companies are frequently unable to use the social marketing approaches because of inadequate understanding of the problems. Specialists of social marketing underline that lack of information about consumers' behavior at the companies result in their ineffective actions (Hieke and Harris, 2016).

Social marketing applies traditional marketing instruments to study the consumers' behavior in relation to healthy nutrition (Glanz et al., 2008; Gordon et al., 2006). Most significant of them is ensuring consumers' awareness about food products' labeling. Labeling is an integral part of products' packaging. It provides product or brand identification, provides information about product manufacturing, composition, use. Labeling of the food products helps the consumers in case if they have knowledge or motivation for use of such information (Rotfeld, 2009). To ensure healthy nutrition it is necessary that the consumers had the habit of reading the labels. Activities and incentives of social marketing improve the consumers' competences and attitudes to labeling. Numerous studies in this sphere confirm that identification of the consumers' behavior in relation to labeling is possible on the basis of in-depth study of the target audience. In addition, we should mention that with respect of consumer behavior and social marketing, certain studies are conducted in Georgia (Apil et al., 2008; Jashi and Todua, 2013). There is studied food security (Meskhia, 2016) and attitude of Georgian consumers to the food products (Todua et al., 2013; Todua and Dotchviri, 2015 a; Todua and Dotchviri, 2015 b), as well as the consumers' and farmers' attitude to genetically modified food products (Todua et al., 2015; Todua et al., 2017; Todua and Gogitidze, 2017). Studying of some issues of labeling of the food products in Georgia is quite interesting (Mghebrishvili and Urotadze, 2016; Todua, 2017; Todua, 2018). At the same time, it should be noted that the issues of effect of the food products' labeling on Georgian consumers' healthy nutrition are not properly studied and require proper scientific researches. Regarding significance of the mentioned problem we have conducted the market research with the aim of studying of the effects of food products labeling on consumers' healthy nutrition. 


\section{Research Methodology}

Research was conducted in two stages, based on the qualitative and quantitative research methods. At the first stage the qualitative study was conducted, including methods of focus groups and in-depth interviews (Malhotra, 2004). Participants of the qualitative research were selected so that to cover all categories of target market. At this stage the hypotheses were formulated and priorities were identified for further researches. At the second stage we used the method of consumers' questioning and as the research instrument we have selected the questionnaire consisting of several structured questions. The questionnaire included information about the respondents' consent and confidentiality, as well as explanations related to the research and completion instructions. In the questionnaire the five-point Likert scale was used. Questioning was conducted applying methods of electronic and face to face interviews. In the research we have used the self-administered questioning method to avoid errors caused by subjective approach of the interviewer. Sample selection was based on random method. The research area included several Georgian cities: Tbilisi, Kutaisi, Batumi, Sighnaghi, Gori, Zugdidi and Senaki. Regarding 95\% confidence interval and 4\% error, 1200 respondents aged over 18 were interviewed (among them $40 \%$ males and $60 \%$ - females). Obtained results were processed by means of statistical software SPSS. In the research was formulated hypotheses with the focus on impact of food products' labeling on buying behavior in relation to the healthy nutrition.

H1: Awareness in labeling of the food products positively impacts buying behavior related to healthy nutrition;

$\mathrm{H} 2$ : Reliability to the information on the packages of food products positively affect buying behavior related to healthy nutrition.

\section{$3 \quad$ Research Results}

Analysis of the market research findings show that most part of the interviewed (85\%) was aware in healthy nutrition issues though, there are common problems that should $b$ necessarily taken into consideration in studying the consumers' awareness in relation to healthy nutrition (see Fig. 1). In this respect, the following points should be emphasized: most respondents regard that the healthy food products are pleasant and are not harmful for human health. Absolute majority of the interviewed regard that they are not indifferent to what they eat and in case of having desired food, only physical exercising is not sufficient. Quite few respondents believe that healthy nutrition is empty eccentricity and nothing more. At the same time, the research showed that $35 \%$ of the respondents clearly understand the risks to health associated with nutrition, $35 \%$ of them are concerned about excessive weight problem, associating it to unhealthy food. $70 \%$ of the 
respondents are ready to accept nutrition limitations if this affect positively their health; $45 \%$ of the respondents take into consideration the professionals' recommendations related to healthy nutrition. There was also established that for $75 \%$ of the respondents taste of the food and whether it is good for health or not is of great significance. According to the research, $28 \%$ of the respondents are sure that their nutrition is healthy; $32 \%$ make efforts to make their nutrition close to healthy one, as far as possible and $21 \%$ of the respondents regard that their nutrition is less balanced that required by the principles of healthy nutrition. $19 \%$ of the interviewed regard that they cannot have balanced, healthy and diverse food.

\section{Figure 1: Levels of the respondents' awareness in healthy nutrition (in \%)}

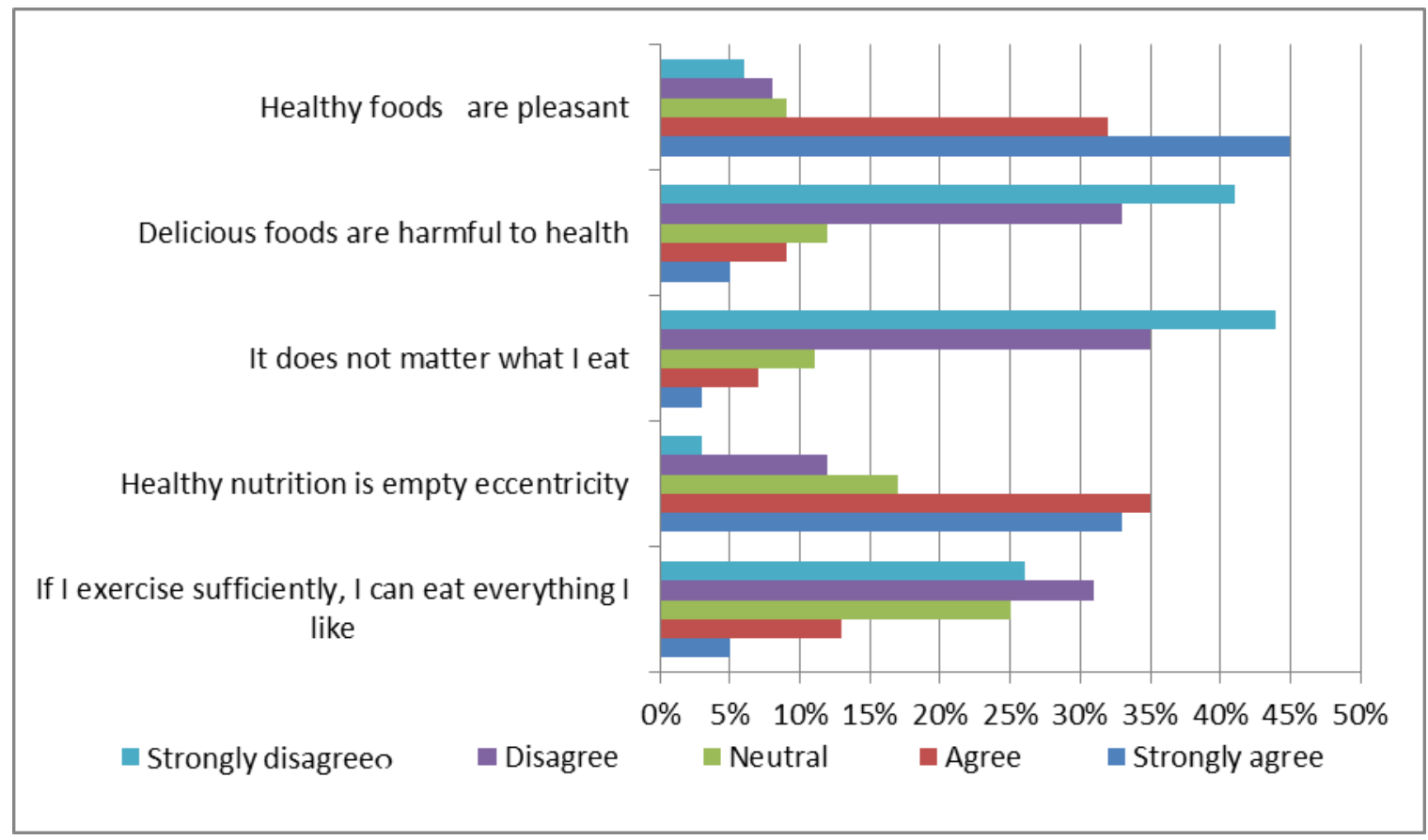

Research showed that Georgian consumers show their buying attitude towards healthy nutrition, mostly by paying attention to the information on the product packages. Such attitude, primarily, shows up in relation to the labeling. Research showed that Georgian consumers basically agree that the labeling is of great significance in making buying decision (see Fig. 2). At the same time, they perceive the purpose of food labeling with respect of healthy nutrition in different manner. In particular, $67 \%$ of the respondents stated that labeling is mostly for information purposes (provide information about the product). $22 \%$ of the interviewed associates labeling purpose with product identification, $9 \%$ - emotional impact on the consumers, resulting in buying of the product and only $2 \%$ regard that labeling is intended for motivation purpose. Dispersion analysis shows that awareness in the purpose of food products' labeling is positively affected by the age of respondents $(F=33.161, P=0.004)$, average monthly incomes $(F=3.038, P=0.001)$ and family status (for the single consumers: $F=522.78, P=0.009$; for the consumers with the 
families: $F=463.46, P=0.009$ ). As for the gender, it does not affect awareness in the purpose of food labeling (for the female consumers: $F=537.12, \quad P=0.095$; for the male consumers: $F=584.36, \quad P=0.095)$.

Figure 2: Frequencies of the consumers' attitudes to labeling of the food products

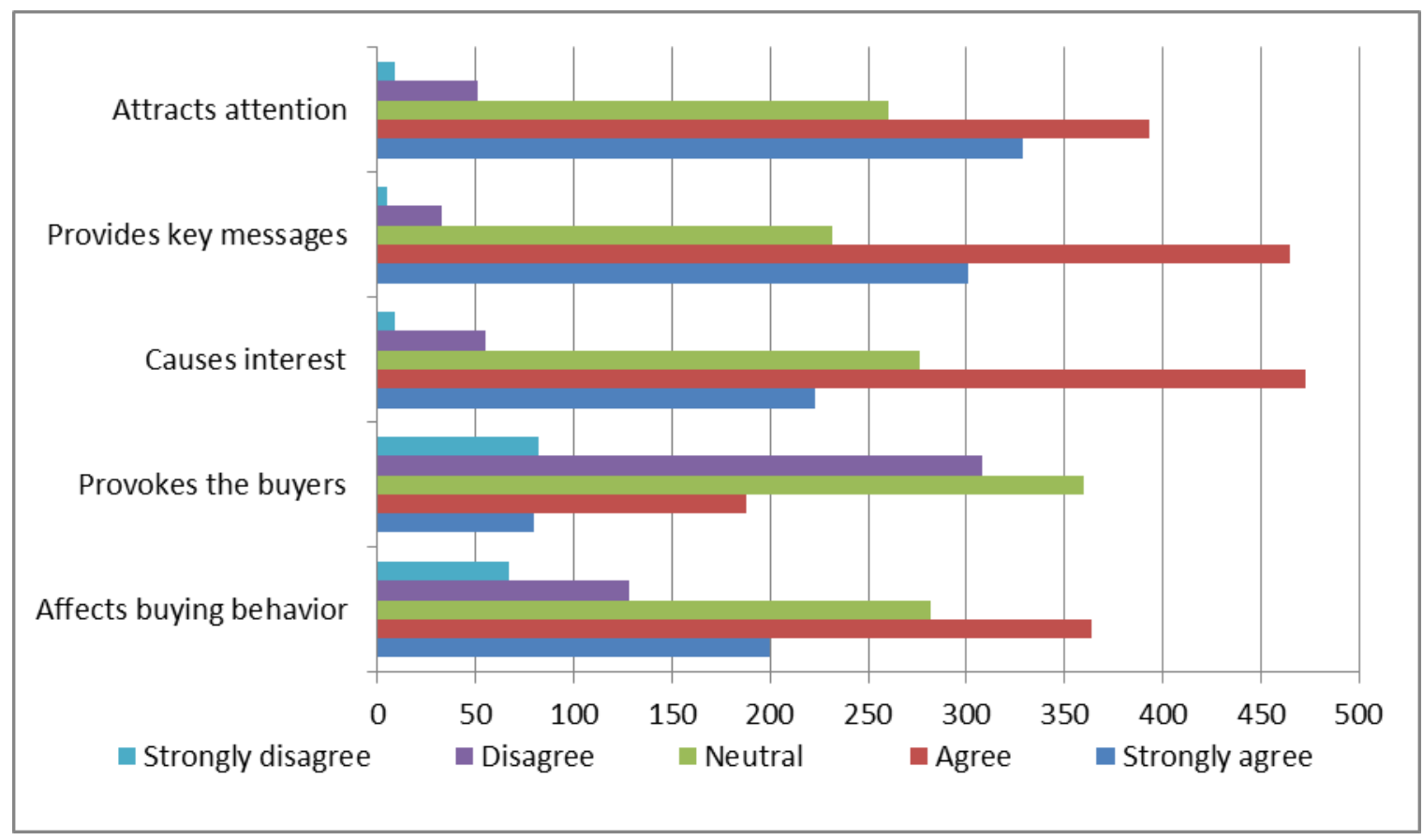

The research showed that the consumers have different opinions about requirements to food labeling. Most of the respondents (44\%) regard that information on the label should contain reliable information. For $31 \%$ of the interviewed the main thing is that the information should be clear, for $18 \%$ of them - apparent and for $7 \%$ - sufficient. At the same time, the analysis shows that with regard of healthy nutrition, requirements to labeling of the food products are impacted by the monthly income of the respondents' families $(F=2.544, P=0.011)$ and education $(F=2.127, P=0.025)$ while age has no such impact $(F=10.352, P=0.797)$.

Research showed that to ensure healthy nutrition, $12 \%$ of the respondents trust the information on food labels, 59\% of them mostly trust this information, $20 \%$ of the respondents has more or less trust to it, $8 \%$ trusts rarely and $1 \%$ do not trust at all. Analysis shows that trust to the information on the food labels is affected by the consumers' age $(F=35.249, P=0.019)$. Respondents aged from 18 to 25 show particular trust (see Fig. 3). It should be also mentioned that the consumers' evaluation of the determinants of such trust is non-uniform. In particular, $34 \%$ of the respondents expresses trust towards information on the food label where the manufacturer is known. $24 \%$ of the interviewed trusts only the information that is logical and well grounded, $22 \%$ known products and $21 \%$ - known brands. 
Conducted market research allows distinguishing of Georgian consumers' types, with respect of their attitude to healthy nutrition that could be used by the marketing specialists as the consumer segments and orient their market offers of their major products towards them. Such segments are as follows:

Figure 3: Frequencies of the respondents' reliability to the information on food product packages (by ages)

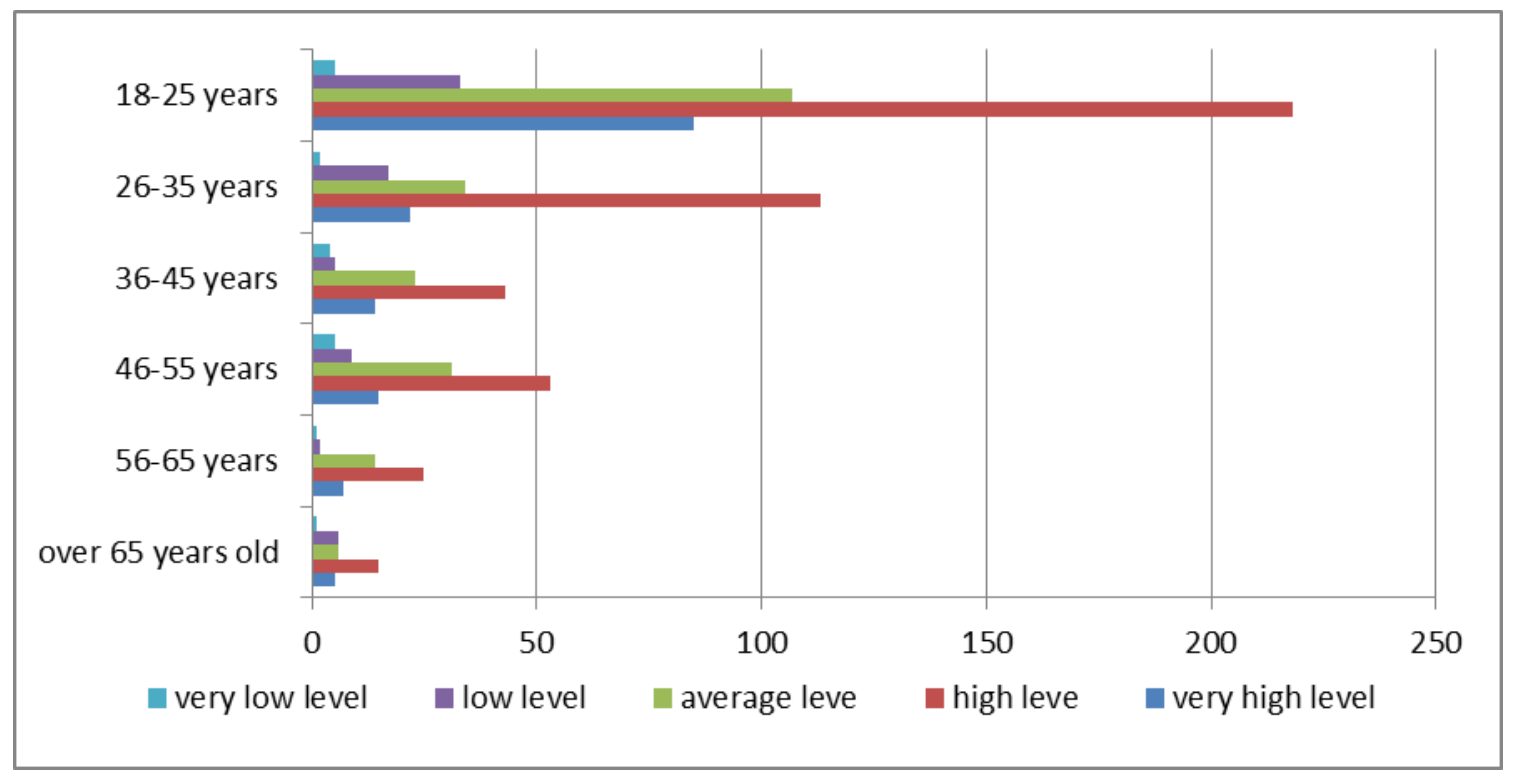

- Consumers, whose buying preferences related to healthy nutrition are mostly oriented towards customary food products. Characteristics of such type include low price and relevant quality. There are such customers in all age groups.

- $\quad$ Consumers following healthy lifestyle. These include consumers younger than 40 and older than 60 . For them the key issues include product content, quality of raw materials and technological processing. In this segment, based on the incomes, there are several strata. Millennium generation (consumers aged from 21 to 34 ) is particularly distinguished. They are ready to pay additionally for the products good for health. Active lifestyle, care about their health and financial capabilities stimulate them to buy more. Though, at the same time, such consumers are stricter. In their opinion, healthy nutrition should be tasty as well. Therefore, these people are the major buyers of premium products.

- $\quad$ Consumers, whose buying preferences, related to healthy nutrition, are not shaped well. Age of such type of consumers could be conditionally determined as from 40 to 60 years. This group tends towards the second type of the consumers.

To prove $\mathrm{H} 1$ hypothesis formulated above we applied One Way ANOVA F-Test. First of all, we determined how consumers' awareness in food products' labeling influence the buying behavior related to healthy nutrition (see Table 1). Dispersion analysis showed that such impact is quite significant $(F=1.701, p=0.049)$. 
Table 1: Dispersion analysis of the influence of awareness in food labeling on buying behavior related to healthy nutrition

\begin{tabular}{|l|c|c|c|c|c|}
\hline \multicolumn{5}{|c|}{ Independent variable: buying behavior related to healthy nutrition } \\
\hline & $\begin{array}{c}\text { Sum of } \\
\text { squares }\end{array}$ & $\mathrm{df}$ & Mean square & $\mathrm{F}$ & $\mathrm{P}$ \\
\hline $\begin{array}{l}\text { Awareness in } \\
\text { labeling }\end{array}$ & .866 & 3 & .289 & 1.701 & .049 \\
\hline Error & 263.346 & 650 & .405 & & \\
\hline
\end{tabular}

At the further stage we studied the impact of trust to information on the food package on buying behavior related to the healthy nutrition (see Table 2). It turned out that trustworthiness of the information on package in this case is significant $(F=8.867$, $\mathrm{p}=0.000$ ).

Table 2: Dispersion analysis of the impact of reliability of information on the food packages on the buying behavior related to healthy nutrition

\begin{tabular}{|l|c|c|c|c|c|}
\hline \multicolumn{5}{|c|}{ Dependent variable: buying behavior related to healthy nutrition } \\
\hline & $\begin{array}{c}\text { Sum of } \\
\text { squares }\end{array}$ & $\mathrm{df}$ & $\begin{array}{c}\text { Mean } \\
\text { square }\end{array}$ & $\mathrm{F}$ & $\mathrm{P}$ \\
\hline $\begin{array}{l}\text { reliability of } \\
\text { information on the } \\
\text { package }\end{array}$ & 17.976 & 3 & 5.992 & 8.867 & .000 \\
\hline Error & 674.400 & 998 & .676 & & \\
\hline
\end{tabular}

Analysis shows that in both studied cases the statistical significance $P$ is no more than 0.05 . Hence, there was found statistically significant relation between the variables under consideration at 0.05 level, confirming both hypotheses formulate above.

\section{Conclusions}

Regarding the research results, the conclusions may be made about the attitude of Georgian consumers to impact of food labeling on healthy nutrition:

- $\quad$ Georgian consumers are aware in impact of nutrition on health and they are ready to change their behavior related to nutrition. In addition, taste of the food, together with the opinion about how good it is for health significantly impact the consumers' choice;

- In choosing healthy food products, the female consumers are more oriented towards recognized brands while the males mostly rely on information on the label. 
- With age, selecting healthy food products, Georgian consumers pay less and less attention to the brands. With improvement of the financial status, when making decision on buying of the healthy food products orientation towards the brands only gradually decreases. Such attitude is conditioned by the fact that wealthier consumers behave more reasonably, relying on choosing of the characteristics of the food products.

- Consumers following the principles of healthy nutrition are more interested in the information on the labels of food products than recognition of the brands. Such behavior can be explained by the fact that as a rule, healthy nutrition for Georgian consumers is not associated with buying of the widely advertised food products.

- For certain part of Georgian consumers brand is the signal of high quality nutrition, as well as guarantee that given food product does not contain food additives harmful for health. Hence, such consumers less tend towards getting familiar with the information on the label. In addition, it should be noted that education level of Georgian consumers does not influence on familiarization with the information on the product packages.

- Our research has confirmed that there is a statistically significant correlation between healthy nutrition and awareness in labeling of the food products. Research confirmed that labeling of the food products provide useful information allowing Georgian consumers to ensure healthy lifestyle for them.

This study provides basis for obtaining of objective data for the purpose of development and improvement of the healthy food products, as well as for further study of the respective consumers demand in Georgian market. The research results showed that it is necessary to provide more information to Georgian consumers about healthy nutrition. For this, activities should be supported to provide awareness in importance of healthy nutrition, healthy lifestyle and significance of food labeling. Research results would be useful for people engaged in food business in Georgia, for formation of global vision of the consumers' attitude to healthy nutrition allowing them setting of the key trends in domestic market development.

\section{$5 \quad$ Acknowledgment}

The author gratefully acknowledges the support of Center of Marketing Research at the Ivane Javakhishvili Tbilisi State University.

\section{References}

Apil, A.; Kaynak, E. and Todua, N. (2008) Georgian Consumers Evolution of Products Sourced From a Geographically Close Proximity Country. Journal of Euromarketing, Vol. 17, No. 3/4, pp.199-218. Caplan, P. (1997) Food, health and identity. London: Routledge.

Charles, N. and Kerr, M. (1988) Women, food, and families. Manchester: Manchester University Press. 
Donovan, R. (2011) The role of social marketing in public health program. Australian Review Public Health, Vol.10, No.1, pp. 23-40.

Fischler, C. (1988) Food, self and identity. Social Science Information, Vol. 27, No.2, pp: 275-292.

Food and Agriculture Organization of the United Nations (2016). Food security, Nutrition and Peace. Rome: FAO, [online]. http://www.fao.org/3/a-i5678e.pdf. (Accessed 5 March 2019)

Food and Agriculture Organization of the United Nations (2017) The State of Food Security and Nutrition in Europe and Central Asia. Budapest: FAO , [online]. http://www.fao.org/3//8194EN/i8194en.pdf (Accessed 5 March 2019)

Food and Agriculture Organization of the United Nations (2017) The State of Food Security and Nutrition in the World 2017. [online]. http://www.fao.org/3/a-i7695e.pdf (Accessed 5 March 2019)

Food and Agriculture Organization of the United Nations and World Health Organization (2014) Report of the Joint FAO/WHO Secretariat on the Second International Conference on Nutrition. Rome: FAO and WHO [online]. http://www.fao.org/3/a-at764e.pdf (Accessed 5 March 2019)

Food and Agriculture Organization of the United Nations and World Health Organization (2015) United Nations Decade of Action on Nutrition (2016-2025). Towards country-specific SMART commitments for action on nutrition. Rome: FAO and WHO [online]. http://www.fao.org/3/a-i6130e.pdf . (Accessed 5 March 2019)

Glanz, K.; Rimer, B. and Viswanath, Th. (2008) Health behavior and health education: theory, research and practice, 4th Ed., San Francisco: Jossey-Bass.

Gordon, R.; McDemont, K.; Stead, M. and Angus, K. (2006) The effectiveness of social marketing interventions for health improvement: what's the evidence? Public Health, Vol. 120, No.12, pp. 1133-1139.

Grunert, K. G.; Fernández-Celemín, L.; Wills, J. M.; Storcksdieck Genannt Bonsmann, S. and Nu-reeva, L. (2010) Use and understanding of nutrition information on food labels in six European countries. Z Gesundh Wiss Vol. 18, No.3, pp. 261-277.

Hieke, S. and Harris, J. (2016) Nutrition information and front-of-pack labeling: issues in effectiveness. Public Health Nutrition, Vol. 19, No.12, pp. 2103-2105.

Jashi, C. and Todua, N. Behavior Changing through of Social marketing (Georgian Case). Proceedings of third World Social Marketing Conference. Toronto (Canada). 2013. pp. 95-97.

Malhotra, N. (2004) Marketing Research: an Applied Orientation. 4th ed., Upper Saddle River, NJ: Prentice Hall.

Meskhia, I. (2016). Food security problems in post Soviet Georgia. Annals of Agrarian Science. Vol. 14. pp. 46-51.

Mghebrishvili, B. and Urotadze, E. (2016) Characteristics of Food Products Labeling in Georgia. Proceedings of International Scientific Symposium "Economics, Business \& Finance", Jurmala, pp. 135-138.

Oxfam Georgia (2017) Research on the status of food security and nutrition. Tbilisi: Oxfam Georgia, [online]. http://www.bridge.org.ge/uploads/files/docs/847703 RESEARCH-ON-THE-STATUS-OFFOOD-SECURITY-AND-NUTRITION For web.pdf (Accessed 5 March 2019) 
Robinson, N. (2014) Ageing population will drive food innovation. Food Manufacture, Vol. 89, No.5, pp. $25-2$.

Rotfeld, J. (2009). Health information consumers can't or don't want to use. The Journal Consumers Affairs, Vol. 43, No.2, pp. 373-377.

Todua, N. (2017) Influence of Food Labeling Awereness on healthy behavior of Georgian Consumers. Ecoforum Journal, Vol. 6, No.2.

Todua, N. and Dotchviri, T. (2015) Anova in Marketing Research of Consumer Behavior of Different Categories in Georgian Market. Annals of Constantin Brancusi University of Targu-Jiu. Economy Series, No 1, pp. 183-190.

Todua, N. and Gogitidze, T. (2017) Marketing Research of Attitudes Towards Genetically Modified Crops by Georgian Farmers. Annals of'Constantin Brancusi'University of Targu-Jiu. Economy Series. No. 1, pp. 69-76.

Todua, N. (2018) Impact of food labeling on consumers buying decision (Georgian case). International Journal of Innovative Technologies in Economy, Vol.1, pp.38-43.

Todua, N. and Dotchviri, T. (2015) On the Marketing Research of consumer prices and inflation process. British Journal of Marketing Studies. Vol.3, No.2, pp. 48-57.

Todua, N., Babilua, P., \& Dochviri, T. (2013). On the Multiple Linear Regression in Marketing Research. Bulletin of the Georgian National Academy of Sciences, Vol. 7, No. 3, pp. 135-139.

Todua, N.; Gogitidze, T. and Phutkaradze, B. (2017) Georgian Farmers Attitudes towards Genetically Modified Crops. Economics World, Vol. 5, No.4, pp. 362-369.

Todua, N.; Gogitidze, T. and Phutkaradze, J. (2015) Georgian consumer attitudes towards genetically modified products. International Journal of Management and Economics, Vol. 46, No.1, pp. 120136.

United Nations (2015) Transforming our World: The 2030 Agenda for Sustainable Development. [online]. https://sustainabledevelopment.un.org/post2015/transformingourworld (Accessed 5 March 2018)

World Health Organization (2013) Health 2020: a European policy framework and strategy for the 21st century. Copenhagen: WHO Regional Office for Europe [online]. http://www.euro.who.int/ data/assets/pdf file/0011/199532/Health2020-Long.pdf (Accessed 5 March 2019)

World Health Organization (2016) Ambition and Action in Nutrition 2016-2025. Geneva: WHO. [online]. https://apps.who.int/iris/bitstream/handle/10665/255485/9789241512435-eng.pdf?sequence=1 (Accessed 5 March 2019)

World Health Organization (2018) World health statistics 2018: monitoring health for the SDGs, sustainabl development goals. [online]. https://apps.who.int/iris/bitstream/handle/10665/272596/9789241565585-eng.pdf?ua=1 (Accessed 5 March 2019)

World Health Organization (2014) European Food and Nutrition Action Plan 2015-2020. Copenhagen: WHO Regional Office for Europe, [online]. http://www.euro.who.int/ data/assets/pdf file/0008/253727/64wd14e FoodNutAP 140426.pdf (Accessed 5 March 2019) 